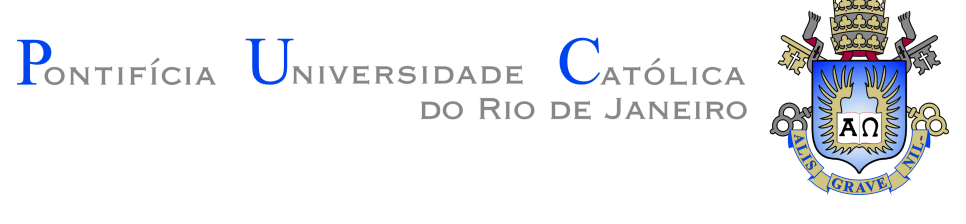

Yan Moreira do Rêgo Barros

\title{
Brazilian mutual funds life cycle analysis
}

Dissertação de Mestrado

Thesis presented to the Programa de Pós-graduação em Economia da PUC-Rio in partial fulfillment of the requirements for the degree of Mestre em Economia.

Advisor : $\quad$ Professor Ruy Ribeiro

Co-advisor: Professor Walter Novaes Filho 


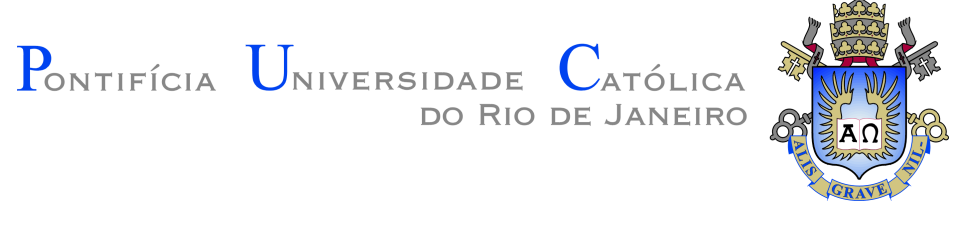

Yan Moreira do Rêgo Barros

\section{Brazilian mutual funds life cycle analysis}

Thesis presented to the Programa de Pós-graduação em Economia da PUC-Rio in partial fulfillment of the requirements for the degree of Mestre em Economia. Approved by the Examination Committee.

Professor Ruy Ribeiro

Advisor

Departamento de Economia - PUC-Rio

Professor Walter Novaes Filho

Co-advisor

Departamento de Economia - PUC-Rio

Professor Marcelo Medeiros

Departamento de Economia - PUC Rio

Professor Márcio Garcia

Departamento de Economia - PUC Rio

Rio de Janeiro, September the 16th, 2019 
All rights reserved.

\section{Yan Moreira do Rêgo Barros}

B.A. in Economics by Brasília University (Brasília, Brasil), 2016.

Bibliographic data

Rêgo Barros, Yan Moreira do

Brazilian mutual funds life cycle analysis / Yan Moreira do Rêgo Barros; advisor: Ruy Ribeiro; co-advisor: Walter Novaes Filho. - Rio de janeiro: PUC-Rio, Departamento de Economia, 2019 .

v., 34 f: il. color. ; $30 \mathrm{~cm}$

Dissertação (mestrado) - Pontifícia Universidade Católica do Rio de Janeiro, Departamento de Economia.

Inclui bibliografia

1. Economia - Teses. 2. Macroeconomia - Teses. 3. Fundos Mútuos;. 4. Mortalidade;. 5. Nascimento;. 6. Estratégias; . I. Ribeiro, Ruy. II. Novaes, Walter. III. Pontifícia Universidade Católica do Rio de Janeiro. Departamento de Economia. IV. Título. 


\section{Acknowledgments}

I have a lot to thank my family, who supported my path. To my friends, who were always present. I also thank my advisors, Ruy Ribeiro and Walter Novaes, who guided this work.

This study was in part financed by the Coordenação de Aperfeiçoamento de Pessoal de Nível Superior - Brasil (CAPES) - Finance Code o01. 


\section{Abstract}

Rêgo Barros, Yan Moreira do; Ribeiro, Ruy (Advisor); Novaes, Walter (Co-Advisor). Brazilian mutual funds life cycle analysis. Rio de Janeiro, 2019 · 34p. Dissertação de mestrado - Departamento de Economia, Pontifícia Universidade Católica do Rio de Janeiro.

Funds close and open over time. The existing evidence is that those that close are those with lower cumulative returns in the period prior to closing. This dissertation shows that this closing dynamic also appears in the Brazilian stock funds market. In a sample of 1192 equity funds, from 2002 to 2016, 448 funds closed. Of these, 39 funds lead to the opening of another under the same management. I show that open-ended closing is typically accompanied by increased return volatility, which I interpret as an attempt to change the investment strategy previously followed. However, this change does not change the manager's abnormal return, as estimated by Carhart's 4-factor model. Finally, I show that the likelihood of fund closure increases with the number of funds opened by the manager in the month prior to closing. This suggests that managers open new funds before closing others to minimize the chance of losing investors.

\section{Keywords}

Mutual Funds; Mortality; Born; Strategies. 


\section{Resumo}

Rêgo Barros, Yan Moreira do; Ribeiro, Ruy; Novaes, Walter. Análise do ciclo de vida dos fundos mútuos brasileiros. Rio de Janeiro, 2019. 34p. Dissertação de Mestrado - Departamento de Economia, Pontifícia Universidade Católica do Rio de Janeiro.

Fundos fecham e abrem ao longo do tempo. A evidência existente é de que os que fecham são aqueles com retorno acumulados menores no período anterior ao fechamento. Essa dissertação mostra que tal dinâmica de fechamento também aparece no mercado de fundos de ações brasileiro. Em uma amostra de 1192 fundos de ações, de 2002 a 2016, 448 fundos fecharam. Destes, 39 fundos levam a abertura de um outro sob a mesma gestão. Eu mostro que o fechamento com abertura é tipicamente acompanhado de um aumento da volatilidade dos retornos, que interpreto como uma tentativa de mudar a estratégia de investimento anteriormente seguida. Tal mudança não altera, entretanto, o retorno anormal do gestor, estimado pelo modelo de 4 fatores de Carhart. Por fim, mostro que a probabilidade de fechamento de fundos aumenta com o número de fundos abertos pelo gestor no mês anterior ao fechamento.Isso sugere que gestores abrem novos fundos antes de fecharem outros para minimizar a chance de perder investidores.

\section{Palavras-chave}

Fundos Mútuos; Mortalidade; Nascimento; Estratégias; 


\section{Table of contents}

1 Introduction $\quad 9$

2 Literature Review $\quad \mathbf{1 3}$

3 Data Description $\quad 17$

4 Are funds that close similar to those that open? $\quad \mathbf{2 1}$

4.1 The Volatility of Returns 21

4.2 Abnormal Returns 22

5 Probability of Closures $\quad \mathbf{2 5}$

6 Conclusions $\quad 31$

7 Bibliographic References 33 


\section{List of tables}

Table 3.1 Closing and Opening of Funds from 2002 to $2016 \quad 18$

Table 3.2 Descriptive Analysis of Brazilian Equity Funds 19

Table $3 \cdot 3$ Description of the Age of Brazilian Equity Funds 20

Table 4.1 Difference in Return Volatility between Groups 22

Table 4.2 Carhart 4 Factor Model for Funds that Closing and Funds that Open 23

Table 5.1 Probit Regression $\quad 26$

Table 5.2 Baseline Hazard 28

Table $5 \cdot 3$ Hazard-Cox Regression 29 


\section{1}

\section{Introduction}

Companies have life cycles, which go through the maturity foundation and eventual death (see, among others, Kaplan, Sensoy and Strömber (2005). In non-financial companies, the life cycle is typically accompanied by changes in the products offered to customers. In the investment fund market, these changes are more subtle: Investment funds are born, grow and die offering their clients the same service: purchases and sales of financial assets. They try to differentiate themselves from rivals by publicizing innovations in their investment strategies as, for example, changes in the composition of the portfolio, or in which economic factors will guide the composition of the portfolio (Hortasçu Syverson [2004]).

It is known, however, that investment fund returns are not entirely under the control of their managers. Some fund managers may have been fortunate enough to invest in the shares of companies associated with important innovations in the economy, while others may have been unlucky enough to retain in their portfolios shares of companies displaced by the innovators. Distinguishing luck from competence and bad luck from incompetence is not a trivial task in the fund market (Fama French [2010], Ercolani et al [2018]). Faced with this difficulty, investors are guided by the accumulated returns of the funds when deciding which ones to invest in. In fact, an extensive international literature on investment funds shows that funds that accumulate positive returns grow, and those that accumulate negative returns languish and die, as shown by BROWN and GOETZMANN (1995). 
The literature that documents the relationship between investment flows and fund returns typically interprets this correlation as caused by investors. However, another interpretation has been little explored. Fund managers who accumulate negative returns may suggest investors close, to explore investment strategies more in line with recent innovations in the economy. Or, alternatively, they can close them to erase their negative returns from investors' memories, keeping their strategies in a new fund with a "clean" return history. Are such strategies relevant in the Brazilian fund market? If so, which of your strategies is most relevant? Death and birth of funds to implement new strategies? OR death and birth to erase the memory of the market? Answering these questions is the main objective of this dissertation.

The starting point for this study is an unbalanced panel of $119^{2}$ equity funds in Brazil, covering the period from January 2002 to December 2016, with monthly data, in which pension funds and funds indexed to Ibovespa were excluded. In this sample there were 105 funds in 2002, rising to 884 funds in 2013 and ending with 706. Although we have many fund births, there are also many closings. With the economic crisis in 2015, 106 died, which represented a $15 \%$ reduction in the number of equity funds in the sample period in Brazil.

As the number of funds has grown enormously, the number of births is greater than that of deaths. Consistently with Hoffman (2018) and Goetzmann et al (1995), the average return on funds that closed were below the sample average. In other words, the probability of death of equity funds is highly affected by performance. This effect is much more present in the analysis of the impact of the 12-month return than in the 3-month cumulative return, so that in the estimates the only statistically significant effect was that of the 
12-month cumulative return, with a marginal effect of each percentage point. of return in the average probability of closing of 0.5 .

For the purposes of this dissertation, the most important is what happens after closing the sample funds (448 in Brazil). In many them, the manager who closes the fund opens a new one a month before closing. This result begs the question: will the new funds love investments that are the same as those closed or different? To answer this question, I look separately at the returns of funds that closed and funds opened in anticipation of closing.

More specifically, I calculate the difference in the standard deviation of the return of the funds that closed, using its last 12 months of return, in relation to the average volatility of the return of the funds that survived the entire sample period in the year in which the fund in question closed. The average result of this difference was $0.64 \%$. I also calculate the difference in the standard deviation of the return of funds that opened a month before the closing of another family fund, this time using the return of the initial twelve months of this fund, with respect also to the funds that survived the entire sample period, obtaining an average difference of $0.29 \%$. We have, then, that the volatility of funds that closed is substantially higher than that of funds that opened.

In theory, managers change strategies to add value to their investments. Was the increase in volatility in open funds accompanied by an increase in abnormal returns? A second test of the returns of funds that opened and closed shows that the abnormal return of funds that opened (alpha of Fama-French-Carhart) is $0.09 \%$ per month, while the abnormal return of those that closed is $-0.49 \%$. The alpha of those who opened did not prove 
to be statistically significant, although the alpha of those who closed is statistically significant at $1 \%$. Therefore, we answer yes to the suggested question.

In addition to the clear difference in abnormal returns, there was a reduction in the average volatility of returns, given by open funds and in relation to closed funds, with both groups (those that closed and those that opened) more volatile than the surviving funds the entire sample period.

The multivariate analysis of the probability of closing funds brings to light another dimension of the closing and opening process of equity funds in Brazil. Using a Probit regression to estimate the average probability of closing funds, I show that the number of funds opened by the manager in the month prior to the observed return is positively correlated with the closing of the fund. This result suggests that managers act strategically before closing their funds. They open a new fund a month earlier to minimize the loss of customers at the close of the fund. This does not depend on whether the manager changes his strategy on the new fund or not.

The structure of the dissertation follows as follows: we have the literature review of Brazilian funds and the life cycle of foreign funds in chapter 1, descriptive analysis of the data in chapter 2, statistical differences between the funds that close to those who replace them in chapter 3 , probability of closing in chapter 4 and conclusion as chapter 5 . 


\section{Literature Review}

Several studies have already been carried out on the Brazilian funds market. Many of them are from analyzes of abnormal returns, others on flows and we even have part of the explanation of higher returns in the case of funds not affiliated with commercial banks, a result that is also valid for Brazil.

One of the main papers on the fund market in Brazil is that of Kaminsky, G. et al (2004), who examines the exchange strategies in the mutual fund market in emerging countries in Latin America, from April 1993 to January 2004. 1999. They find that it is not possible to reject the null hypothesis that there is no use of the momentum strategy, that is, the sale of losing shares and the purchase of winning shares. More than that, they also show that this type of strategy becomes even more used in periods of crisis in emerging countries.

Silva, J. et al, (2011) studies anomalies in the pricing of shares in IPOs (Initial Public Offering) on the São Paulo Stock Exchange (Bovespa), for the period from 2004 to 2007, where they obtained a total of 106 IPOs. They note that there is a strong overvaluation in stock prices on the first day of opening, so that abnormal returns are between $4.80 \%$ and $9.26 \%$. In addition, it was possible to observe significant losses in the value of the portfolios when they excluded the first day of trading: at the end of the sixth month, $-11.52 \%$ and reaching $-41.79 \%$ at the end of 24 . Another interesting fact brought up is that, between 2004 and 2007, the number of individual investors rose from 117 thousand to around 406 thousand. 
Hoffman (2018) also studies the causes of the higher return of independent funds in relation to those that are affiliated with commercial banks. In his dissertation, he showed that Brazilian mutual funds affiliated with commercial banks have an average performance of up to $2.36 \%$ less return than independent funds. Using Active Share to measure active risk (measure of activity), it was found that the difference in Active Share between affiliated and independent funds comes to explain $29.6 \%$ of the performance difference, thus, managers of funds affiliated with banks seek less risky actions and, therefore, they earn less return. In contrast, in this dissertation an analysis of possible differences between the life cycle of affiliated funds and those of non-affiliates was also made, showing that, although the probability of death of affiliates is greater, that of birth is also.

Regarding the determinant factors for closing mutual funds, although there is no Brazilian case study, there are for other countries, the first being by BROWN GOETZMANN (1995). This article performs a Probit estimation to show for the first time in the estimates that low performances increase the likelihood of death for mutual funds in the United States. Lunde et at (1999) analyzed British funds, so that they investigated the determinants of the conditional probability of closing UK funds. For this, they perform hazard ratio estimations in relation to age, finding that the estimated hazard ratio curve is convex. This implies that younger and older funds in the UK, from 1972 to 1995, are less likely to close, on average. Together, estimation was also performed via Probit, in order to compare the results, which proved to be robust.

Horst et al. (2001) extended the aforementioned studies by employing a probit model to investigate the survival of US Mutual funds. The authors 
share the same methodology as Brown and Goetzmann (1995), except that quarterly data were used. They found that lagged quarterly returns, the age of the fund and an aggregate time effect all had a significant impact on fund closings. Higher returns and old age increased the likelihood of survival, as well as quarterly returns. In addition, the significant effect of the reported time indicated that macroeconomic variables affected the mutual fund's probabilities of survival as well. It is noteworthy that the pattern of accumulated return coefficients estimated in your model for income funds was monotonically decreasing, while for growth funds it was in a concave form, which indicates that recent past performance is relatively more important for the survival of funds income than for growth funds.

There is also a study for the Australian case, with Cameron et al (2003), where they examined the life cycle of funds in this country. Using data from Australian mutual funds from 1968 to 1999, the authors estimate using the proportional model of the parametric and nonparametric hazard-cox, where they find very similar results for both models, which shows a somewhat unexpected robustness of the parametric models for this model. type of analysis. In the regression, they show how the hazard ratio behaves over time for different types of distribution functions inserted. As in the paper by Lunde et al (1999) mentioned above, they find an inverted U shape in terms of the sensitivity of the hazard ratio to time. This indicates that younger and older funds are more sensitive to variations in return, size and rate of spending.

The most recent paper on the subject is that of $\mathrm{Bu}$ et al (2009), where the authors use both logistic regression and the hazard-cox model, for the United States from October 1998 to September 2004. With the logistic regression, they show that it is not only the short-term (3 months) or long-term (12 
months) accumulated returns that influence the probability of closing, but also the expense ratio, turnover, price to book ratio and price to sales ratio. As for age, it is only relevant for newer funds, as well as in the Brazilian case studied in this dissertation. The hazard-cox model showed that, as in the Australian case, the United States has an invested, concave u-shaped hazard ratio, but when compared to Australian funds, it is seen that there is a much less learning period, which can explained by the greater maturity of American funds, reflected mainly by low transaction costs. 


\section{3 \\ Data Description}

The main source of data for this dissertation is the Quantum Finance Platform ${ }^{1}$, which documents, among other things, stock funds operating in Brazil, their managers, returns, total assets and age. The sample covers the years 2002 to 2016 , excluding pension funds, stock index funds and FICs ("Quota Investment Funds"), which were included in a single count, that is, all the FICs of a fund were excluded with the exception of one for each fund, so that there is no double count. With this database, it was possible to analyze the life cycle of Brazilian funds and their characteristics, such as opening and closing rates, number of funds per year and their evolution.

Openings increased until the middle of 2008. With the beginning of the economic crisis, the growth rate dropped to almost half: $18.2 \%$ in 2009 , after a growth that reached $32.6 \%$ in 2007 . The number of new funds dropped from 138 in 2008 to 96 in 2009 . As for the number of closed funds, we see that this value is increasing in practically the entire period, except for 2013 and 2014. It is noted, even though the increase in the number of stock funds was in 2013, with 755 funds. This sample fund numbers are shown in Table 3.1:

${ }^{1}$ I am grateful to Pompeu Hoffman for providing the database used by him in his dissertation, which included the same period of analysis, from January 2002 to December 2016. 
Table 3.1: Closing and Opening of Funds from 2002 to 2016

\begin{tabular}{cccccc} 
Year & $\begin{array}{c}\text { Born Funds } \\
\text { During The Year }\end{array}$ Rate Of Openings (\%) & $\begin{array}{c}\text { Dead Funds } \\
\text { During The Year Rate of Closures (\%) }\end{array}$ The End Of The Year \\
\hline 2002 & 8 & 7.27 & 0 & 0.00 & 110 \\
2003 & 8 & 6.78 & 0 & 0.00 & 118 \\
2004 & 20 & 14.49 & 0 & 0.00 & 138 \\
2005 & 31 & 18.34 & 0 & 0.00 & 169 \\
2006 & 52 & 23.53 & 0 & 0.00 & 221 \\
2007 & 105 & 32.31 & 1 & 0.31 & 325 \\
2008 & 141 & 30.79 & 8 & 1.75 & 458 \\
2009 & 101 & 18.20 & 4 & 0.72 & 555 \\
2010 & 125 & 18.77 & 14 & 2.10 & 666 \\
2011 & 98 & 13.63 & 45 & 6.26 & 719 \\
2012 & 110 & 14.15 & 71 & 9.37 & 758 \\
2013 & 111 & 13.81 & 65 & 8.08 & 804 \\
2014 & 62 & 7.74 & 65 & 8.11 & 801 \\
2015 & 11 & 1.56 & 106 & 15.01 & 706 \\
2016 & 0 & 0.00 & 81 & 12.96 & 625 \\
\hline
\end{tabular}

Table 3.1 consists of all equity funds opened from January 2002 to December 2016, in Brazil, according to the Quantum Finance Platform. Both the opening and closing rates represent the proportion of open and closed funds, respectively, in relation to the previous year.

Of the total of 1192 funds, only 335 are not incorporated in a fund complex, or family. Such families of funds are formed in such a way that they provide a greater range of investment possibilities for the investor. In this way, it can be expected that there will be differentiation of product within the family, with a low correlation between the portfolios of the funds that compose it (Khorana and Servaes, 2003). When we compare funds that are not part of a family to those that are in one, we have that the death rate of independent funds is $10 \%$, whereas when the fund is part of a family, that probability drops to $5.87 \%$. When analyzing intra-families, we have that the probability of death of a fund conditional to the birth of another in the previous period is $9.29 \%$ and the correlation between births and shows in families is $12.1 \%$.

As Elton, Gruber \& Green (2006) make clear, there are great advantages in forming a family of funds with different products, as they attract a greater range of investors due to their greater mobility between investments, so that transaction fees the family may be smaller.

Another relevant aspect of the stock market in Brazil is their affiliation with commercial banks. In the sample, 455 funds are affiliated with commercial banks and 737 are not affiliated. The following table, in turn, associates returns and flows to the four types of disunited funds: those belonging to a 
family, those not belonging, those affiliated with banks and the independent ones.

Table 3.2: Descriptive Analysis of Brazilian Equity Funds

\begin{tabular}{|c|c|c|c|c|}
\hline & \multicolumn{2}{|r|}{ Lonely } & \multicolumn{2}{|c|}{ Part of Family } \\
\hline & Affilisted & Independent & Affiliated & Independent \\
\hline Flow Median & -16 & $.0 .14 \%$ & $-0.55 \%$ & $-0.38 \%$ \\
\hline 3-Month Accumulated Median Return & $3.63 \%$ & $3 \%$ & $3.06 \%$ & $2.31 \%$ \\
\hline 12-Month Accumulated Median Return & $15.49 \%$ & $10.66 \%$ & $10.26 \%$ & $16.01 \%$ \\
\hline Mean flow & $-0.15 \%$ & $-0.39 \%$ & $-0.13 \%$ & $-0.11 \%$ \\
\hline 3-Month Accumulated Mean Return & $3.72 \%$ & $2.71 \%$ & $2.77 \%$ & $4.27 \%$ \\
\hline 12-Month Accumulated Mean Return & $12.9 \%$ & $8.5 \%$ & 6.074 & $7.09 \%$ \\
\hline Number of Observations & 30 & 305 & 443 & 595 \\
\hline
\end{tabular}

Table 3.2 shows the medians and averages of fundamental variables in the life cycle analysis of funds, such as the accumulated flow and returns, with monthly data taken from the Quantum Finance Platform, from January 2002 to December 2016. The analysis is separated first between those who are lonely and those who are part of a family, they were then separated between those who are affiliated with commercial banks and those who are independent

In the table the average returns of non-affiliates who belong to a family is higher than the average returns of affiliated funds, I try to accumulate the return of 3 months as well as 12 months, which will be used in the regressions to measure the short-term effects ( 3 months) and long term (12 months) in the probability of closing average. The median cumulative return of 3 months is higher in the case of affiliates, while we have the biggest difference in the median cumulative return of 12 months, being $16.01 \%$ for non-affiliates and $10.26 \%$ for affiliates. In the case of funds that do not belong to families, the results are different. Equity funds affiliated with commercial banks that are not part of a family of other funds end up obtaining higher averages and medians of accumulated returns of 2 and 12 months. We can also see that the average and median capital flow of non-affiliates is higher than that of affiliates, but non-affiliates that belong to the family of funds are those that have the highest average flow in the sample. This flow variable refers to the paper by Sirri \& Tufano (1998), in which they calculate the flow using the following equation: 
Table 3.3: Description of the Age of Brazilian Equity Funds

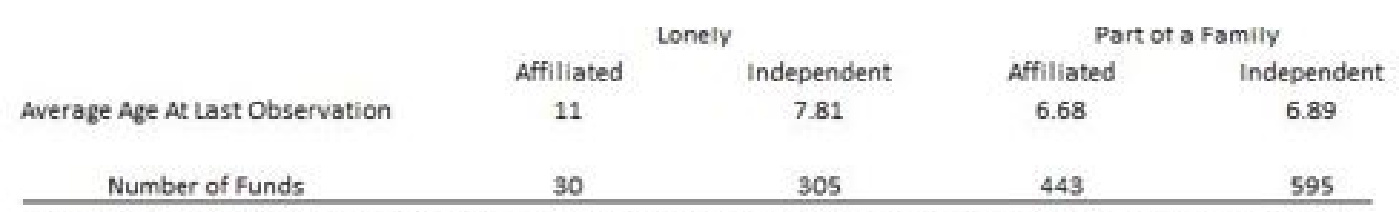

Table 3.3 shows the average age of Brazilian funds from 2002 to 2016, extracted from the Quantum Finance Platform, counting only the fund's last observation, in years. It also shows the total funds for each group over the period.

$$
\text { Flow }_{i, t}=\frac{T N A_{i, t}-T N A_{i, t-1} \times\left(1+R_{i, t}\right)}{T N A_{i, t-1}}
$$

Where TNA is the Total Net Assets of fund $i$ in quarter $t$ e ... is the gross return of fund i monthly in quarter t. Finally, the age of the funds is described in the table:

The first line shows the average age of the component funds of each group listed in the last observation period of each fund, that is, even if the fund did not close until 2016, its age at the time was computed. Therefore, we can see a clear difference in the average age between funds that are lonely and those that make up families. The solitary funds that are affiliated with commercial banks have an average age much higher than the others, 11 years old, and even those that do not belong to families also have a higher average age in the sample. As for family funds, we do not have large differences in average age between the affiliate and independent groups. It should also be noted that the number of funds affiliated with commercial banks and that are independent from commercial banks is low, only 30 funds. In addition, the sum of the number of funds is greater than the total funds in the sample, due to the fact that some funds that were solitary have started to compose families, that is, at least one new fund has been opened, or the opposite : some small families performed poorly in some of their funds and chose to close them, betting on their best performing fund. 


\section{4}

\section{Are funds that close similar to those that open?}

Two are the main hypotheses to be tested. The first, if managers close funds at a loss to open others that are basically the same, and the second, close themselves to open another that will follow different strategies. To test these hypotheses, the first part of this chapter compares the volatilities of the funds that open replacing a close and those that close and are replaced, while the second checks their abnormal returns.

\section{1}

\section{The Volatility of Returns}

Between 2002 and 2016, 448 funds closed. Of these, thirty-nine are associated with open funds in the month prior to closing. In this section, we estimate the volatility of returns in the twelve months prior to closing for those that closed and the volatility of returns from the thirty-nine funds that were opened in the twelve months after opening, both measured by standard deviation. We then calculated the average difference of these volatilities in relation to the volatility of the return on funds that survived the entire sample period, for the year corresponding to the opening or closing. This difference is in the table below: 
Table 4.1: Difference in Return Volatility between Groups

Closed Funds
Openned Funds
Difference
Table 4.1 shows the difference in volatility of the return of funds that closed and of
funds that opened with respect to the volatility of the return of funds that survived
the entire period of the sample, from January 2002 to December 2016. This volatility
was measured by the deviation standard in the last twelve months of life of the fund
that closed and by the standard deviation of the return in the first twelve months of
life of those who opened, being compared with the group of survivors in the year
corresponding to the opening or the closing.

The evidence is that the volatility of the return on funds that closed is substantially higher than the volatility of the return on funds that opened, and the difference in means between the groups is statistically significant.

\section{2}

\section{Abnormal Returns}

Do changes in strategies generate an expected return? Using the same subsamples mentioned in section 4.1, then the 4 -factor regressions of FamaFrench-Carhart (1997) mentioned above were calculated by:

$$
R_{i}-R_{m}=\alpha+\beta_{m}\left(R_{m}-R_{f}\right)_{t}+\beta_{h m l} H M L_{t}+\beta_{s m b} S M B_{t}+\beta_{u m d} U M D_{t}+\epsilon_{t}
$$

Where $R_{i}$ refers to the gross return of fund i, $R_{m}$ is the market return (Ibovespa) and the factors seek to capture the effect of market premiums: $R_{m}-R_{f}$ is the excess return of the market with respect to at the basic interest rate, HML (high minus low) is the difference in return between a portfolio composed of stocks with book to market and the return of a portfolio with stocks with low book to market, SMB (small minus big) is the difference of return between a portfolio of shares with low capitalization in the Brazilian market and a portfolio composed of shares with large capitalization. UMB refers to the difference in return between the portfolios of 12-month winners and 12-month losers. All these data were taken from the Nefin website (financial

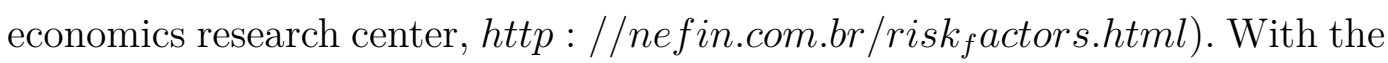


estimation of the factors, we then calculate the difference between the fund's expected return and the realized return, so that we have the excess abnormal return for each month, the alpha, shown in the table below for each group:

Table 4.2: Carhart 4 Factor Model for Funds that Closing and Funds that Open

$$
\text { Dead Funds Born Funds Survivers }
$$

\begin{tabular}{cccc} 
Alpha & $-0.49^{* *}$ & 0.09 & $0.07^{* *}$ \\
HML & -0.06 & $-0.11^{*}$ & $-0.05^{* * *}$ \\
SMB & $0.14^{* *}$ & $0.12^{*}$ & $0.18^{* * *}$ \\
UMD & $-0.17^{* *}$ & -0.05 & $0.03^{* * *}$ \\
RM-RF & $0.86^{* * *}$ & $0.83^{* * *}$ & $0.75^{* * *}$ \\
$\mathrm{R}^{2}$ & 0.39 & 0.49 & 0.53 \\
\hline
\end{tabular}

Table 4.2 shows the regression of 4 Carhart factors for three different samples. The first consists of funds that have closed and been replaced. The second, from funds that replaced those that closed, a month earlier. In the third column, we have the same calculation for the funds that survived the entire sample period, from January 2002 to December 2016. The data are monthly, obtained from the Quantum Finance Platform.

In the table we have an estimate of alphas of three groups: Those that closed and were replaced by a fund in the same family in the previous period, those new funds that were born in the families, replacing those that closed a month earlier and for the survivors. The returns used are those of the 12 months prior to closing in the case of the dead, the twelve months after opening in the case of funds that were born and every month of the sample period for those that survived. It is noted that the alpha of the funds that closed is very negative, which shows its difficulty in overcoming even fixed income and, possibly, the biggest explanation for its closing, a subject that will be discussed in the next section. The funds that were opened in this family of those that closed have alphas statistically equal to zero, since the null hypothesis that it is different from zero is not rejected. This difference in excess return is relevant and shows some effectiveness in the strategy of replacing the closed-end fund. However, these returns, which refer only to the first year after the opening, cannot exceed the average monthly alpha of the 
funds that survive the entire sample period. As for the factors, there are some changes in the magnitudes, the largest being in the case of SMB, in which in the case of funds that were born it was not statistically significant. The market return minus that of Ibovespa varied little and represents the greatest impact on excess return. 


\section{5 \\ Probability of Closures}

Funds that are born replacing another fund have different strategies than the one that was replaced, but do not generate abnormal returns. In this section, I show the determinants of the closing of funds by the following Probit Model:

$$
\begin{aligned}
& \text { Death }_{t, i}=\beta_{0}+\beta_{1} \operatorname{Lag} 1 \text { NewFund }{ }_{i, t}+\beta_{2} \text { Return }_{i, t}+\beta_{4}{\text { Return } 12_{i, t}+} \\
& \beta_{5} \text { Newtotal }_{i, t}+\beta_{6} \text { Flow }_{i, t}+\beta_{7} \text { TNAFamily }_{i, t}+\beta 8 \text { Age }_{t}+\beta_{9} \text { Turnover }_{i, t}+ \\
& \beta_{10} \operatorname{Bank}_{i, t}(2)(3)+\beta_{11} \operatorname{Ibov6}_{i, t}(3)+\beta_{12} \operatorname{Selic}_{i, t}(3)+\epsilon_{t}
\end{aligned}
$$

Where the dependent variable will have a value of $o$ if fund $i$ remains open in period $t$ and value 1 if fund $i$ closes at t. Lag-1FNewFund is the number of funds that were opened in the fund i family at t-1. Return3 and Return12 are the accumulated returns in three and twelve months, respectively, in each month $\mathrm{t}$ for each fund i, Newtotal is the number of funds that appear in the market in $\mathrm{t}$ (including those from the same family), Flow is the flow of each fund in each period, Age shows the age of the fund in each t, Turnover represents the volatility of fund $i$ in $t$, Bank is a dummy variable that has value one if the fund is affiliated with a commercial bank and zero if the opposite, valid only for equations 2 and 3 . Ibov6 is the accumulated return of the Bovespa index in each $\mathrm{t}$ for each fund i.e. Selic is the historical series of the Selic rate in the period, for each i, $\epsilon$ is the model error.

Using the equation above, both Probit and Hazard-Cox regressions were estimated for robustness. Probit regressions can be seen below: 
Table 5.1: Probit Regression

\begin{tabular}{|c|c|c|c|}
\hline \multirow{2}{*}{ Death } & (1) & (2) & (3) \\
\hline & $\%$ & $\%$ & $\%$ \\
\hline Lag-1 New Funds in Family & $0.39^{* * *}$ & $0.33^{* * *}$ & $0.33^{* * *}$ \\
\hline 3-Month Accumulated Return & -0.01 & 0.12 & -0.21 \\
\hline 12-Month Accumulated Return & $-0.50^{* * *}$ & $-0.49^{* * *}$ & $-0.51^{* * *}$ \\
\hline New Funds All Market & $0.00^{* *}$ & $0.00^{* * *}$ & $0.00^{* * *}$ \\
\hline Flow & $-1.82^{* * *}$ & $-1.79^{* w *}$ & $-1.79^{* * *}$ \\
\hline TNA-Family & $0.00^{*}$ & 0.00 & 0.00 \\
\hline Age & $-0.11 * * *$ & $-0.06^{* * *}$ & $-0.06^{* * *}$ \\
\hline Turnover & -0.04 & -0.03 & -0.03 \\
\hline Bank & & $0.18^{* *}$ & $0.19^{* * *}$ \\
\hline Ibovespa 6 months & & & -0.12 \\
\hline Selic & & & $-0.08^{* * *}$ \\
\hline
\end{tabular}

Table 5.1 the Probit regression of the binary variable Death in the factors above for Brazilian funds from 2002 to 2016, using monthly data from the Quantum Finance Platform. The Ibovespa return is also accumulated and the variable Bank is a value dummy if a fund is affiliated with a commercial bank. Lag-1 New Funds in the Family counts the number of equity funds opened one month before the closure of another in the same family of funds.

There are three different regressions in the table. The first is the simplest and captures the most known effects in the literature for probability of death, as seen in Bu et al (2009). The novelty is the captured effect of adding a new fund to the family of funds. Each new fund added to the family with a period lag represents an increase in the probability of death of $0.39 \%$, statistically significant at $1 \%$, in equation one, even though also controlling for the total number of new funds, which proved to be null. This would corroborate the hypothesis that the number of funds in the family enables lower transaction rates and that it would facilitate the decision to close the fund to replace it with another one, since a large part of the capital would remain in the family and shows that the subsamples of funds that close and they are replaced and those that replace make up a significant part of the analysis of the causes of 
stock fund closings in Brazil.

The effect of the return on the probability of death is also interesting. Using the same concept as Bu et al (2009) in which the cumulative three-month return would show short-term pressure effects from closing performance, and the cumulative three-month return would show short-term pressure effects from closing performance, and the cumulative twelve-month return under long-term pressure, it was possible to verify the opposite result for the Brazilian case: here, the biggest effect (and only statistically significant) is the long-term, where each extra percentage point of return decreases the average probability of closing by $0.5 \%$. For the United States, the authors find much more pronounced short-term pressure, from $0.33 \%$ for each accumulated threemonth return point and $0.008 \%$ for the twelve-month accumulated return. The biggest effect is the flow, where each higher percentage of capital flows reduces the average probability of closing by $1.82 \%$. The size of the family was not significantly different from zero and we have that each additional year of survival decreases the average probability of closing by $0.11 \%$, which indicates a greater propensity to close young Brazilian funds.

As for the other determinants of the closing of equity funds in Brazil, still following what was done for other countries as controls, we chose to use Turnover as a risk measure, as was seen with Agarwal et al. (2015), where such measure is calculated as follows:

$$
\text { Turnover }_{i, t}=\frac{\text { Min }_{\text {Purchases }}, t, \text { Sell }_{i, t}}{T N A_{i, t}}
$$

However, as we can see in the regressions, this risk measure does not significantly affect the probability of death. In the second regression, a commercial bank affiliation dummy was added. We see that funds affiliated with commercial banks in Brazil have an average probability of closing slightly higher than the independent ones by $0.18 \%$, even controlling for other factors such as return and flow, which as seen in Hoffman (2018) are systematically lower when there is affiliation with a bank. commercial.

The third column adds two variables to the analysis, namely the accumulated return of the Bovespa index and the Selic rate. Both were included in order to measure how the heating of our economy can affect the fund market. Although the Ibovespa return coefficient is not significant, we have 
to note that each percentage of extra interest in the Selic rate increases the probabilities of closing by up to $0.08 \%$.

In a complementary way and in order to test both the robustness of the result and to better distinguish the effect of the age of the funds on the probability of closing, the Hazard-Cox model (1972) was also used, first estimating the baseline hazard ratio, following the molds of Lunde, Timmermann \& Blake (1999):

Table 5.2: Baseline Hazard

Baseline Hazard

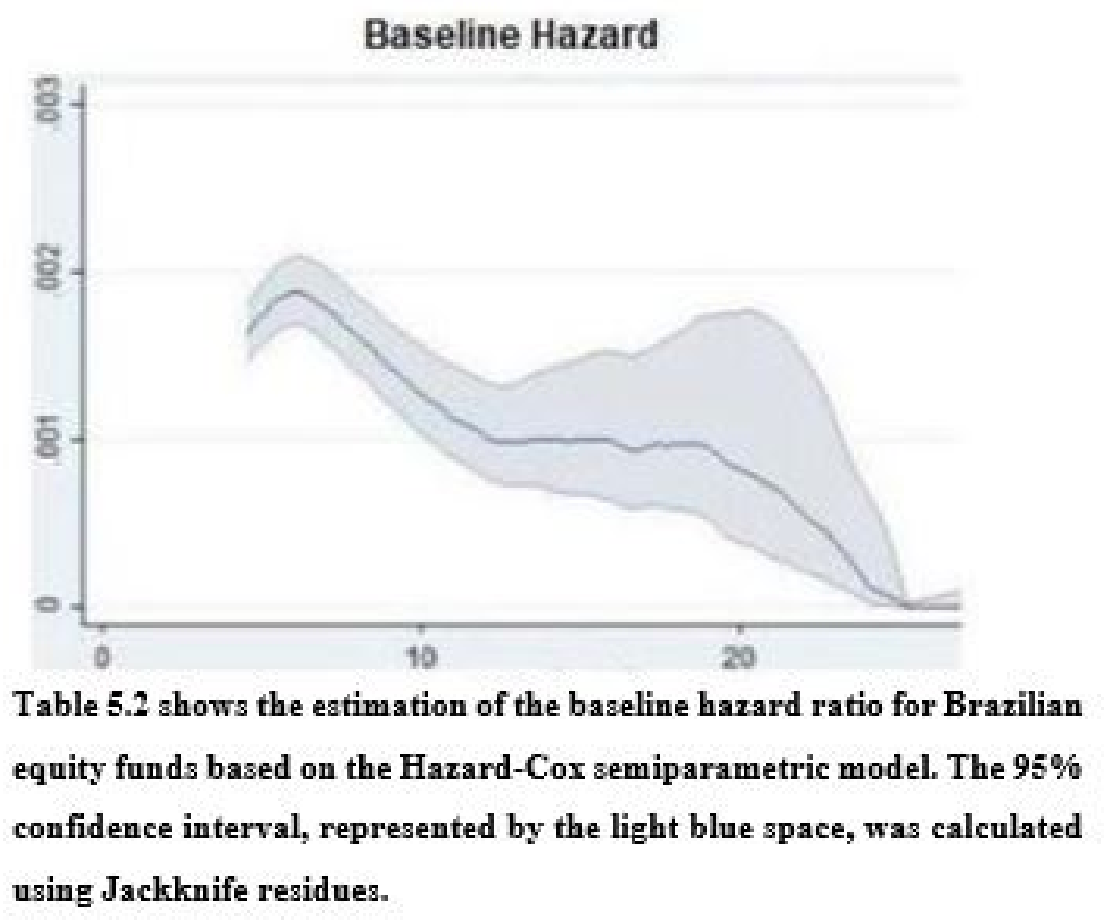

It becomes interesting to estimate the baseline hazard ratio because it shows us the sensitivity of the hazard function over the years, showing that when they reach the average of 6 years of life, funds are at their peak of sensitivity of the hazard function, with about $2.4 \%$ of annualized hazard ratio, against $1.2 \%$ hazard ratio between 10 and 20 years of life. These values show how, over the years, the average probability of death of Brazilian funds behaves in relation to the coefficients to be analyzed, which in this dissertation were the same as those of the Probit regression: 
Table 5.3: Hazard-Cox Regression

\begin{tabular}{|c|c|c|c|}
\hline Death & (1) & (2) & (3) \\
\hline & $\%$ & $\%$ & $\%$ \\
\hline Lag-1 New Funds in Family & $2.63^{* * *}$ & $2.46^{* 40}$ & $2.38^{* * *}$ \\
\hline 3-Month Accumulated Return & 0.89 & 0.85 & 1.52 \\
\hline 12-Month Accumulated Return & $0.22^{* * * *}$ & $0.23^{* * *}$ & $0.21^{* * * 3}$ \\
\hline New Funds All Market & $1.08^{* * *}$ & $1.08^{* * *}$ & $1.07^{* * *}$ \\
\hline Flow & $0.01^{* * *}$ & $0.01^{* * *}$ & $0.01^{* * *}$ \\
\hline TNA-Family & 1.01 & 1.00 & 1.00 \\
\hline Age & $0.85^{* \cdots *}$ & $0.85^{* * *}$ & $0.84 * \cdots$ \\
\hline Turnover & 0.74 & 0.74 & 0.73 \\
\hline Bank & & $1.76^{847}$ & $1.75^{4 * *}$ \\
\hline Ibovespa 6 months & & & $0.06^{* * *}$ \\
\hline Selic & & & 0.91 \\
\hline
\end{tabular}

Table 5.3 shows the Hazard Cox Proportional Model, regression of the binary variable death in the above factors, using monthly data from January 2002 to December 2016 extracted from the Quantum Finance Platform. The returns in the table are accumulated with the indicative of the number of months accumulated and the variable Bank is a value dummy if a fund is affiliated with a commercial bank and zero otherwise. Lag-1 New Funds in the Family counts the number of equity funds opened one month before the closure of another fund in the same family of funds.

Unlike the interpretation of the marginal effects of the Probit model seen above, the hazard ratio is a relative effect between groups. What happens is that when its value is equal to one, the regressor has no effect on the dependent variable. Values below one indicate a decrease in the probability of death for the regressor in question and the magnitude of the effect is proportional: a hazard ratio of 0.5 means that the average probability of death is half for that regressor, in relation to the survival group.

Therefore, the hazard ratio values above 2.3 for the creation of a new fund lagged between the regressions indicate that in those families in which a new fund was created, the probability of death of another fund is twice as high as in the group in which there is no there was background birth. Following this reasoning, we have that the group of mutual funds affiliated with commercial 
banks has 1.76 and 1.75 times the chance of death of the funds that are not affiliated, for equations 2 and 3, respectively. Again, large capital flows have a negative effect on the probability of death of this estimate, but even more accentuated. As for short- and long-term return pressures, this regression followed Probit's path again, indicating significant pressures only for returns accumulated in twelve months. In fact, the only difference between the regressions, in terms of results, is that the number of new funds on the market has an impact of around $8 \%$ on the death rate over life and is significant. The size of the family once again proved to be very close to zero. 


\section{6 \\ Conclusions}

There is a sharp drop in the number of funds born in 2008 to 2009 , as well as from 2013 to 2014, years in which Brazil experienced the beginning of crises. In 2014, there were also the largest number of closings of Brazilian funds in the sample period, with 110 closed funds. It was possible to show that a higher Selic rate increases the average probability of death of the funds.

We seek to explore the possible action strategy of a family of funds when it chooses to close one of its funds and replace it with another. When this occurs, two hypotheses arise: The first, that this opening of a new fund reflects a strategic change in the family, in response to changes in demand in the Brazilian financial market, and the second, that they simply chose to close a fund that did not. it was fine to open another one with a similar concept and without major innovations, just for changing the air.

To test these hypotheses, we calculated both the 4 -factor alpha of Carhart and the volatility of the return separately for the group of funds that died after the creation of another and for those funds that were created immediately before a close. We saw that alphas are much smaller in the case of funds that closed (and that were replaced in the following month), in relation to funds that opened (those that opened in the same family as the closed fund, in the following month) and, even more, with the funds that survive the entire sample period. As for the volatility of the return on funds, those that were born showed reasonably less volatility. The combination of these results suggests that choosing to close the fund that had poor performance to open a new one can bring higher returns on average, measured by the alpha, with less volatility, that is, assuming less risk than the closed funds assumed in their last year. Thus, it can be said that there is a change in investment strategies and that this change really give superior results to those of its predecessors.

Regressions were made that include variables that affect the closing of known funds in this literature, with the inclusion of the number of new funds 
that appear in the family in the month prior to the closing of a fund. This variable showed a positive effect on the average probability of death of the funds and was statistically significant. This result corroborates the hypothesis that the low intra-family transaction costs means that a large part of the invested capital remains in the manager, in some of its funds and shows that there is a positive sign to closing funds when the manager chooses to open a new.

It was also possible to show that, in the Brazilian case, the threemonth cumulative return variable has a low magnitude (-0.01\%) and was not statistically significant. The twelve-month cumulative return variable was found to be relevant both in magnitude and in statistical significance, $-0.5 \%$, significant at $1 \%$. 


\section{7}

\section{Bibliographic References}

AGARWAL, V.; MULLALLY, K. A.; TANG, Y. ; YANG, B.. Mandatory portfolio disclosure, stock liquidity, and mutual fund performance. The Journal of Finance, 70(6):2733-2776, 2015.

BLISS, I. The Method of Probits. Science. 79 (2037), 1934.

BROWN, S. GOETZMAnN, W. Performance Persistence. The Journal of Finance, 1995.

BU, Q \& LACEY, N. Understanding Mutual Funds Termination. Journal of Economics and Finance, 2009.

CARHART, M. M. On persistence in mutual fund performance. The Journal of Finance, 52(1):57-82, 1997.

COX, D. Regression Models and Life-Tables. Journal of the Royal Statistical Society, 1972.

ELTON, E. GRUBER, M \& GREEN, F. The Impact of Mutual Fund Family Membership on Investor Risk. JOURNAL OF FINANCIAL AND QUANTITATIVE ANALYSIS, 2007.

ERCOLANI, M. POULIOT, W \& ERCOLANI, S. Luck versus skill over time: time-varying performance in the cross-section of mutual fund returns, Applied Economics, 2018.

FAMA, E. F.; FRENCH, K. R.. Common risk factors in the returns on stocks and bonds. Journal of Financial Economics, 33(1):3-56, 1993.

Fama, E. F.; French. Luck versus Skill in the Cross-Section of Mutual Fund Returns.. The Journal of Finance 65: 1915-1947, 2010. 
HOFFMAN, P. Why do Brazilian bank-affiliated mutual funds underperform?, 2018.

HORST, J. NIJIMAN, T. VERBEEK, M. Eliminating look-ahead bias in evaluating persistence in mutual fund performance. Journal of Empirical Finance. 8:345-373, 2008.

HORTAS, A. \& SYVERSON, C. Cementing relationships: Vertical integration, foreclosure, productivity, and prices. unpublished manuscript, University of Chicago, 2004.

KAPLAN, S. SENSOY, B \& STROMBERG, P. What are Firms? Evolution from Birth to Public Companies. NATIONAL BUREAU OF ECONOMIC RESEARCH, 2005.

LUNDE, A. TIMMERMANN, A \& BLAKE, D. The hazards of mutual fund underperformance: A Cox regression analysis. UCSD Economics Discussion Paper, 1998.

SIRRI, E. R.; TUFANO, P.. Costly search and mutual fund flows. The Journal of Finance, 53(5):1589-1622, 1998. 